International Journal of Engineering \& Technology, $7(4.4)(2018) 30-32$
International Journal of Engineering \& Technology
SPC
Website: www.sciencepubco.com/index.php/IJET
Research paper

\title{
The Influence of Celebrity Endorsement on Consumer's Attitude: A Study Case of Smartphone Brands in Jakarta, Indonesia
}

\author{
Ina Melati, Teddy Indira Budiwan, \&HaryadiSarjono
}

${ }^{1}$ Management Department BINUS Business School Undergraduate Program,Bina Nusantara University, Jakarta, Indonesia 11480

*Corresponding author_E-mail:imelati@binus.edu,tbudiwan@binus.edu,\&haryadi_s@binus.edu

\begin{abstract}
This study analyzes the effect of celebrity endorsement on consumer's attitude towards social media advertising as well as the effect of consumer's attitude towards social media advertising on consumer's purchase intention of smartphone brands in Jakarta. A survey was conducted on 404 university students in Bina Nusantara University. After conducting exploratory factor analysis (EFA) and multipleregression analysis, the result indicates that consumer's attitude towards social media advertising is positively affected by 4 factors: celebrity trustworthiness, celebrity liking, celebrity match-up with product and celebrity familiarity. Attitude towards social media advertising also has a positive impact on consumer's purchase intention of smartphone brands in Jakarta.
\end{abstract}

Keywords:Celebrity Endorsement, Consumer's Attitude towards Social Media Advertising, Purchase Intention, Smartphone Brands

\section{Introduction}

The rapid growth of Internet usage in Indonesia has created opportunities for more economic developments, including smartphone industry, According to International Data Corporation's (IDC) Quarterly Mobile Phone Tracker, smartphone shipments in Indonesia reached 7.9 million units in 2017Q2 (IDC, 2017a). Among the many smartphone vendors, the top 5-smartphone vendors in Indonesia as follows;

\begin{tabular}{|c|c|c|}
\hline Rank & Vendor & 2017Q2 \\
\hline 1 & Samsung & $32.3 \%$ \\
\hline 2 & OPPO & $23.4 \%$ \\
\hline 3 & Advan & $9 \%$ \\
\hline 4 & Asus & $6.9 \%$ \\
\hline 5 & Xiaomi & $3.2 \%$ \\
\hline
\end{tabular}

Source: IDC Asia/Pacific Quarterly Mobile Phone Tracker 2017Q2 (IDC, 2017a)

According to Statista(2017), 28.78\% of Indonesians use mobile internet. Digital marketing is currently adopted widely in Indonesia. Instagram will bring in $\$ 1.53$ billion in mobile ad reve- nue worldwide this year and is a marketer's dream because Instagram ads fit seamlessly into the user browsing experience (LePage, 2016). Using celebrity endorsement would enhance a brand's image or buying confidence, and the effectiveness of advertisements (Chan, Leung Ng, \& Luk, 2013) and creates a great impact on the consumer mind and buying behavior (Arora, 2013). The question arises to investigate here is:What are the perception and attitude of consumers towards smartphone social media advertising using celebrity endorsement? It's also an interesting question to investigate; Does positive perception and attitude of smartphonesocial media advertising using celebrity endorsement influence the consumer's purchase intention?The overall objective of this study is to analyze the effect of celebrity endorsement on consumer's attitude towards social media advertising as well as the effect of consumer's attitude towards social media advertising on consumer's purchase intention of smartphone brands in Jakarta.

\section{Research Methodology}

The research methods of this study were summarized into the research design below:

\begin{tabular}{|c|c|c|c|c|c|c|}
\hline \multirow{2}{*}{\multicolumn{2}{|c|}{ Research Objectives }} & \multicolumn{3}{|l|}{ Research Design } & \multirow[t]{2}{*}{ Time Horizon } & \multirow[t]{2}{*}{ Data Analysis } \\
\hline & & $\begin{array}{l}\text { Data Collection } \\
\text { Method }\end{array}$ & $\begin{array}{l}\text { Research \& Data } \\
\text { Type }\end{array}$ & Unit Analysis & & \\
\hline \multirow[b]{2}{*}{ RQ-1 } & $\begin{array}{l}\text { Explore the perception } \\
\text { and attitude towards }\end{array}$ & Interview & $\begin{array}{l}\text { Qualitative/ } \\
\text { Exploratory }\end{array}$ & \multirow{3}{*}{$\begin{array}{l}\text { Smartphone Users in } \\
\text { Jakarta }\end{array}$} & \multirow{3}{*}{ Cross-Sectional } & Content Analysis \\
\hline & $\begin{array}{l}\text { celebrity endorsements } \\
\text { in social media adver- } \\
\text { tising }\end{array}$ & Survey & $\begin{array}{l}\text { Quantitative/ Explora- } \\
\text { tory }\end{array}$ & & & $\begin{array}{l}\text { Exploratory Factor } \\
\text { Analysis }\end{array}$ \\
\hline RQ-2 & $\begin{array}{l}\text { The Influence of celeb- } \\
\text { rity endorsement in } \\
\text { social media advertis- } \\
\text { ing toward purchase } \\
\text { intention }\end{array}$ & Survey & $\begin{array}{l}\text { Descriptive/ } \\
\text { Associative }\end{array}$ & & & Multiple Regression \\
\hline
\end{tabular}


This research will be conducted in two stages using qualitative and quantitative methods. Qualitative data were collected by in depth interview, meanwhile quantitative data was collected through survey. Qualitative data were analyzed by content analysis, and quantitative data was analyzed by factor analysis. Multivariable regression analysis was conducted to find the influence of celebrity endorsement on attitude towards social media advertising, as well as the effect of attitude towards social media advertising towards the purchase intentions of smartphone brands in Jakarta.

\section{Findings and Discussion}

\subsection{Qualitative Study}

The interview was conducted with 14 university students aged 2023 years old, the analysis then conducted through coding process. The coding process resulted 3 (three) themes, namely: 1). Perception towards Celebrity Endorsement in Social Media Advertising, 2). Factor of Celebrity Endorsement and 3). Factor of Social Media Advertising. The interpretation for each theme as follows:

\begin{tabular}{|l|l|l|}
\hline $\begin{array}{l}\text { Perception towards Celebrity Endorsement in Social } \\
\text { Media Advertising }\end{array}$ & Factor of Celebrity Endorsement & Factor of Social Media Advertising \\
\hline Social Media Advertisement as a Promotion Method & Celebrity Popularity & Product Specification \\
\hline Celebrity in social media advertising of smartphones & Celebrity Positive Image & Memorable Tagline \\
\hline Celebrity Effect on Social Media Advertisement & Celebrity Match-up with Product & User experience \\
\hline Celebrity Effect on Social Media Advertisement & Celebrity Attractiveness & Visually Pleasing \\
\hline & Celebrity Trustworthiness & Model Utilization \\
\hline & Celebrity Liking & \\
\hline
\end{tabular}

\subsection{Quantitative Study}

celebrity endorsement, resulted 4(four) factors with significant $\mathrm{KMO}$ and Barlett's coefficient value.

Total responses were collected by the researcher was 443 , both from online and offline questionnaire. The data were filtered according to the conditions of this study is respondents around 1824 years' old, university student, using smartphone as well as Instagram.

Exploratory Factor Analysis. Exploratory factor analysis in this study is used to explore the factor of celebrity endorsement. The analysis was conducted to validate and determine the factors of

\begin{tabular}{|c|c|c|c|c|c|}
\hline \multirow{2}{*}{ Composition } & \multirow{2}{*}{ Code } & \multicolumn{4}{|c|}{ Component } \\
\hline & & 1 & 2 & 3 & 4 \\
\hline \multirow{3}{*}{ Celebrity Trustworthiness } & CT2 & 0.862 & & & \\
\hline & CT3 & 0.847 & & & \\
\hline & $\mathrm{CT} 2$ & 0.824 & & & \\
\hline \multirow[b]{2}{*}{ Celebrity Liking } & CL2 & & 0.882 & & \\
\hline & CL1 & & 0.874 & & \\
\hline \multirow{2}{*}{ Celebrity Match-up with Product } & CM2 & & & 0.884 & \\
\hline & CM3 & & & 0.816 & \\
\hline \multirow{2}{*}{ Celebrity Familiarity } & CF1 & & & & 0.860 \\
\hline & CF2 & & & & 0.830 \\
\hline \multicolumn{2}{|l|}{ Eigenvalue } & 4.017 & 1.439 & 0.937 & 0.911 \\
\hline \multicolumn{2}{|l|}{$\%$ of Variance } & 44.632 & 15.992 & 10.411 & 10.122 \\
\hline \multicolumn{2}{|l|}{$\%$ of Cummluative } & 44.632 & 60.624 & 71.035 & 81.157 \\
\hline
\end{tabular}

Multiple Regression Analysis was conducted to answer the research questions. The analysis will be conducted in two steps. Firstly, analysis will be between variable CT (celebrity trustworthiness), CL (celebrity liking), CM (celebrity match-up with the product), Celebrity Familiarity and ATSCA (attitude towards social media advertising) to measure the effect of celebrity endorsement in influencing attitude towards social media advertising. Resulted, adjusted $\mathrm{R}^{2}$ value is 0.429 which is varied from $42.9 \%$ in terms of "attitude toward social media advertising", it can be defined by the independent factors in the model. $F=61.989$ with significant level of $0.000<0.05$, which indicate a high significance level, therefore, the regression model is considered overall fit. Secondly, the analysis will be between ATSCA (attitude towards social media advertising) and PI (purchase intentions) to measure the effect of positive perception of social media advertising to purchase intention, resulted adjusted $R^{2}$ value is 0.384 , which is varied by $38.4 \%$ in terms of "attitude toward social media advertising", it can be defined by the independent factors in the model. $\mathrm{F}=252.232$ with significant level of $0.000<0.05$, which indicate a high significance level, therefore, the regression model is considered overall fit

\section{Conclusion}

The qualitative study gives insight and additional knowledge about the perception of smartphone social media advertising using celebrity endorsement. It resulted in three themes, namely, which is summarized into 3 categories, "perception towards celebrity endorsement in social media advertising", "factors of celebrity endorsement" and "factors of social media advertising".

The quantitative result of this study indicated that there are 4 factors of celebrity endorsements that will positively influenced consumer's attitudes towards social media advertising. Furthermore, positive attitude towards social media advertising influenced the purchase intentions of smartphone. Prior to choosing a celebrity for social media advertising, there are 4 factors that need to be considered. This study indicated that celebrity trustworthiness, celebrity liking, celebrity match-up with product and celebrity familiarity significantly influenced the consumer's attitude towards social media advertising. 
Firstly, in using celebrity endorsement on social media advertising, smartphone vendors need to pay attention to the celebrity selected for promotion purposes. If a celebrity had a negative reputation, being associated with scandals, then avoid using the celebrity. Because the market values celebrity that is trustworthy. Secondly, celebrity that is likeable in terms of their appearance and fashion style is perceived positively in social media advertisements, which can be explained by the nature of Instagram itself. The fact that participants can browse photos easily, and still have a rich visual experience, is an appeal of Instagram (Chen \& Chen, 2017). Picture and video content that aesthetically designed will be more preferable for its user. Thirdly, when selecting an endorser, the celebrity needs to be able to transfer his or her image and personality to the advertised product in order to convey the correct message of the advertising to the viewers, who are considered as potential customers of the brand.

The image of a celebrity needs to be suitable to the product advertised. The perfect congruence between endorser and product may lead to great endorser believability through identification process and favorably influence consumer attitudes toward ads and products as well as purchase intention (Langmeyer and Walker, (1991); Kirmani and Shiv, (1998) as cited in Muda \& Musa, 2017). Fourthly, the familiarity of celebrity also affects the attitude towards social media advertising, It can be explained by the frequency of the celebrity seen in print media and internet. The more exposure of celebrity in the media, the more the celebrity is known by the consumer. Lastly, positive attitude towards social media advertising impacted the purchase intention of smartphone brands in Indonesia. When a social media advertising is perceived as informative, interactive, entertaining and credible the effectiveness of a social media advertising will increase. Informative advertisement will give the information of the product features to the viewer and making them aware of the product function. Interactivity of a social media advertisement can be explained by how the advertisement could strengthen the relationship between the consumer and brand.

\section{Acknowledgment}

Our gratitude to our student Virgina for her contribution in this study.

\section{References}

[1] Arora, A. (2013). Celebrity Endorsement: an Effective Marketing Tool. International Journal of Management Prudence, 5(2), 27-32.

[2] Boateng, H., \&Okoe, A. F. (2015). Determinants of Consumers' Attitude towards Social Media Advertising. Journal of Creative Communications, 10(3), 248-258. https://doi.org/10.1177/0973258615614417

[3] Chan, K., Leung Ng, Y., \&Luk, E. K. (2013). Impact of celebrity endorsement in advertising on brand image among Chinese adolescents. Young Consumers, 14(2), 167-179. https://doi.org/10.1108/17473611311325564

[4] IDC, 2017a. Indonesian Smartphone Brands in a Hard Fight as Local Competition Intensifies, IDC Reports [WWW Document]. IDC.com . . URL https://www.idc.com/getdoc.jsp?containerId=prAP42904517 (accessed 1.29.18)

[5] Investment, I. (2016). Internet \& Smartphone Penetration in Indonesia Estimated to Grow Strongly. Retrieved from https://www.indonesia-investments.com/id/news/todaysheadlines/internet-smartphone-penetration-in-indonesia-estimatedto-grow-strongly/item7010?

[6] LePage, E. (2016). All the Social Media Advertising Stats You Need to Know. Retrieved from http://www.marketinghub.today/allthe-social-media-advertising-stats-you-need-to-know/

[7] Muda, M., Musa, R., \&Putit, L. (2017). Celebrity Endorsement in Advertising: A double-edged Sword. Journal of ASIAN Behavioural Studies, 2(3), 21. https://doi.org/10.21834/jabs.v2i3.188
[8] Statista. (2017). Number of internet users in Indonesia 2022. Retrieved from https://www.statista.com/statistics/254456/number-ofinternet-users-in-indonesia/ 